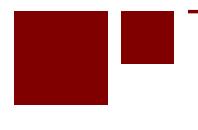

\title{
HOW PREPARED ARE STATE AND LOCAL WORKERS FOR RETIREMENT?
}

\author{
Alicia H. Munnell, Jean-Pierre Aubry, Josh Hurwitz, and Laura Quinby \\ CRR WP 2011-15 \\ Date Released: October 2011 \\ Date Submitted: October 2011
}
Center for Retirement Research at Boston College
Hovey House
140 Commonwealth Avenue
Chestnut Hill, MA 02467

Tel: 617-552-1762 Fax: 617-552-0191

http://crr.bc.edu

\begin{abstract}
Alicia H. Munnell is the director of the Center for Retirement Research at Boston College (CRR) and the Peter F. Drucker Professor of Management Sciences at Boston College's Carroll School of Management. Jean-Pierre Aubry is the assistant director of state and local research at the CRR. Josh Hurwitz and Laura Quinby are research associates at the CRR. The research reported here was performed pursuant to a grant from Great-West Retirement Services. The opinions and conclusion expressed are solely those of the authors and do not represent the opinions or policy of Great-West Retirement Services or Boston College. The authors would like to thank Beth Almeida, Frank Caine, and Nathan Scovronick for helpful comments.
\end{abstract}

(C) 2011, Alicia H. Munnell, Jean-Pierre Aubry, Josh Hurwitz, and Laura Quinby. All rights reserved. Short sections of text, not to exceed two paragraphs, may be quoted without explicit permission provided that full credit, including $\mathbb{C}$ notice, is given to the source. 


\title{
About the Center for Retirement Research
}

The Center for Retirement Research at Boston College, part of a consortium that includes parallel centers at the University of Michigan and the National Bureau of Economic Research, was established in 1998 through a grant from the Social Security Administration. The Center's mission is to produce first-class research and forge a strong link between the academic community and decision-makers in the public and private sectors around an issue of critical importance to the nation's future. To achieve this mission, the Center sponsors a wide variety of research projects, transmits new findings to a broad audience, trains new scholars, and broadens access to valuable data sources.

\author{
Center for Retirement Research at Boston College \\ Hovey House \\ 140 Commonwealth Avenue \\ Chestnut Hill, MA 02467 \\ phone: 617-552-1762 fax: 617-552-0191 \\ e-mail: crr@bc.edu \\ crr.bc.edu
}

Affiliated Institutions:

The Brookings Institution

Massachusetts Institute of Technology

Syracuse University

Urban Institute 


\begin{abstract}
A widespread perception is that state-local government workers receive high pension benefits which, combined with Social Security, provide more than adequate retirement income. This study uses the Health and Retirement Study (HRS) and actuarial reports to test this hypothesis. The major finding from the HRS analysis is that most households with state-local employment end up with replacement rates that, while on average higher than those in the private sector, are well below the 80 percent needed to maintain pre-retirement living standards. Even those households with a long-service state-local worker - those who spend more than half of their careers in public employment - have a median replacement rate, including Social Security, of only 72 percent. And this group accounts for less than 30 percent of state-local households. The remaining 70 percent of households with a short- or medium-tenure state-local worker have replacement rates of 48 percent and 57 percent, respectively. Adding income from financial assets still leaves most state-local households short of the target.

Data from actuarial reports published by state and local pension systems provide part of the explanation for these lower-than-anticipated replacement rates. Only 32 percent of workers (with at least one year of service) who leave state-local employment each year claim an immediate benefit. These individuals have more than 20 years of tenure on average and receive a benefit equal to 49 percent of their pre-retirement earnings. But another 27 percent leave statelocal employment with a deferred benefit based on their earnings at termination, which will decline in value between termination and claiming as wages and prices rise, so it will amount to less than 10 percent of their projected earnings at retirement. And 40 percent leave without any promise of future benefits. The other part of the explanation is that most households with a statelocal worker contain a person employed in the private sector, and replacement rates for private sector workers are considerably lower since many end up with nothing more than Social Security.
\end{abstract}




\section{Introduction}

The replacement rate is a basic measure of the performance of retirement income systems. It gauges the extent to which benefits replace earnings before retirement and thereby allow workers to maintain a reasonable approximation of their pre-retirement standard of living. In the U.S. retirement income system, Social Security provides a basic level of replacement, upon which individuals can build through additional saving. This additional saving comes mainly through employer-sponsored pension plans. Most people in both the public and private sectors save little on their own outside of pensions.

This paper explores the question of replacement rates for state-local government workers. State and local retirement plans are primarily defined benefit, and plan participation is virtually universal. ${ }^{1}$ Upon retirement, state and local employees receive a lifetime annual retirement benefit equal to about two percent of their final average earnings multiplied by their years of tenure. A popular perception is that state-local workers often end up with total retirement income in excess of their pre-retirement earnings. For example, journalists frequently report that state-local benefits replace around 70-80 percent of pre-retirement income, which, combined with Social Security, would produce replacement rates in excess of 100 percent. $^{2}$ Similarly a recent study (Beshears et al. 2011) using hypothetical workers reports mean combined Social Security/defined benefit replacement rates for a large sample of state-local plans that range from 76 percent to 129 percent. ${ }^{3}$ These numbers suggest that state-local workers have more than enough to maintain their lifestyle in retirement. A crucial assumption behind this widespread conclusion, however, is that state and local employees remain at their jobs long enough to take full advantage of the pension system.

To answer that question, this study employs two types of analyses. First, using data from the Health and Retirement Study (HRS), a nationally representative longitudinal survey of older households, it estimates how much people with state-local work experience actually receive in retirement relative to pre-retirement earnings and compares these replacement rates to wellknown benchmarks and to the experience of private sector workers. Second, it uses actuarial

\footnotetext{
${ }^{1}$ Some jurisdictions have introduced a defined contribution plan. For an update on the movement toward defined contribution plans in the state-local sector, see Munnell et al. (2011a).

${ }^{2}$ USA Today (2007). Roughly 70 percent of state and local employees also participate in Social Security.

${ }^{3}$ The replacement rate is calculated after tax and retirement plan contributions: (after-tax automatic retirement annuity income in the first year of retirement)/(after-tax salary in the final year of work - mandatory contributions in the final year of work).
} 
report data on departures from state-local plans to identify those who will receive immediate benefits, those who will receive deferred benefits, and those who leave before vesting; and calculates actual and projected replacement rates for immediate and deferred recipients, using data on workers' expected tenure, final salary, and benefit.

The discussion proceeds as follows. The first section explores how much income people need in retirement and raises some conceptual issues involved in constructing replacement rates. The second section presents replacement rates derived from Social Security and from employersponsored plans for individual workers in the private and state-local sectors. The third section replicates the analysis for households. The fourth section reports how non-pension financial assets affect the replacement rate picture. The fifth section summarizes the actuarial report evidence. The sixth section concludes.

The major finding from the HRS analysis is that most households with state-local employment end up with replacement rates that, while on average higher than those in the private sector, are well below the 80 percent needed to maintain pre-retirement living standards. Even those households with a long-service state-local worker - those who spend more than half of their careers in public employment - have a median replacement rate of only 72 percent. And this group represents less than 30 percent of state-local households. The remaining 70 percent of households with a short- or medium-tenure state-local worker have replacement rates of 48 percent and 57 percent, respectively. Adding income from financial assets closes the gap somewhat, but still most state-local households fall short of the target.

The actuarial report data provide part of the explanation for these lower-than-anticipated replacement rates. Only 32 percent of workers (with at least one year of service) who leave state-local employment each year claim an immediate benefit. These individuals have more than 20 years of tenure on average and receive a benefit equal to 49 percent of their pre-retirement earnings. But another 27 percent leave state-local employment with a deferred benefit based on their earnings at termination, which will decline in value between termination and claiming as wages and prices rise, so it will amount to less than 10 percent of their projected earnings at retirement. And 40 percent leave without any promise of future benefits. The other part of the explanation is that most households with a state-local worker contain a person employed in the 
private sector, and replacement rates for private sector workers are considerably lower since many end up with nothing more than Social Security. ${ }^{4}$

\section{The "Replacement Rate" Concept}

Replacement rates are used to gauge the extent to which older people can maintain their pre-retirement levels of consumption once they stop working. ${ }^{5}$ The most direct approach would be a comparison of household consumption while working with consumption after retirement. But such data are rarely available. An indirect approach is to compare pre- and post-retirement income. ${ }^{6}$ This section briefly reviews what might be considered an adequate level of replacement income and describes some of the conceptual issues involved in constructing replacement rates.

\section{What replacement rate do people need in retirement?}

People clearly need less than their full pre-retirement income to maintain their standard of living once they stop working. One big difference before and after retirement is the extent to which income is taxed. When people are working, their earnings are subject to both Social Security and Medicare payroll taxes and federal personal income taxes. After retirement, they no longer pay payroll taxes, and they pay lower federal income taxes because only a portion of Social Security benefits are taxable. Under current law, individuals with less than $\$ 25,000$ and married couples with less than $\$ 32,000$ of "combined income" do not have to pay taxes on their

\footnotetext{
${ }^{4}$ According to our calculations from the HRS, of married couples with a state-local worker, 23 percent include two state-local workers, 58 percent include a state-local and a private-sector worker, and 19 percent include a state-local worker and a non-worker. Roughly 40 percent of private sector households rely only on Social Security and receive no employer-sponsored pension.

${ }^{5}$ Technically, people are interested in smoothing marginal utility, not consumption. To the extent that they get pleasure from leisure in retirement, they may maintain overall utility with lower levels of consumption after they stop working. The enjoyment of leisure may explain what the literature calls the "retirement-consumption puzzle" namely, the fact that consumption appears to drop as people retire. See Bernheim, Skinner and Weinberg (2001); Banks, Blundell and Tanner (1998); and Hurd and Rohwedder (2003).

${ }^{6}$ In an extension of the replacement rate approach to test whether people are saving optimally for retirement, two recent studies (Engen, Gale, and Uccello 1999; and Scholz, Seshadri, and Khitatrakun 2004) compare people's actual behavior with the behavior that comes out of simulation models. In these simulations, households attempt to smooth their consumption over their remaining lives as they are buffeted by shocks to their wages, employment, and health. Because of these shocks, households with very similar characteristics can end up with very different levels of wealth. These simulations have generally produced results showing that households' actual levels of preparedness look very much like the numbers generated by the simulations, suggesting that people respond rationally to life's events.
} 
Social Security benefits. Above these thresholds, recipients must pay taxes on either 50 or 85 percent of their benefits. ${ }^{7}$

A second reason why retirees require less than their full pre-retirement income is that they no longer need to save a portion of that income for retirement. In addition to contributing to 401(k) plans, many households try to pay off their mortgage before they retire. In retirement, these households no longer need to save and, in fact, can draw on their accumulated reserves. Thus, a greater share of their income is available for consumption.

A final factor often mentioned is that work-related expenses, such as clothing and transportation, are either no longer necessary or are much reduced. Although this factor often tops many analysts' lists, it is relatively small compared to taxes and saving.

While all analysts cite the same factors for why retirees need less than their full preretirement income, they employ different approaches to calculating precisely how much less. The RETIRE Project at Georgia State University has been calculating required replacement rates - that is, retirement income as a percent of pre-retirement earnings - for decades. For an array of pre-retirement earnings levels, they calculate federal, state, and local income taxes and Social Security taxes before and after retirement. They also use the Bureau of Labor Statistics Consumer Expenditure Survey to estimate consumer savings and expenditures for different earnings levels. As of 2008, the Project estimated that a couple with an income of $\$ 50,000$ required 81 percent of pre-retirement earnings to maintain the same level of consumption (see Table 1). Couples earning $\$ 90,000$ needed 78 percent, and couples earning $\$ 20,000$ needed 94 percent, because they save very little before retirement and enjoy less in the way of tax reduction.

\footnotetext{
${ }^{7}$ The percent of Social Security benefits subject to personal income taxation is as follows. Individuals with "combined income" between $\$ 25,000$ and $\$ 34,000$ include 50 percent of benefits; over $\$ 34,000$ they include 85 percent. Couples with "combined income" between $\$ 32,000$ and $\$ 44,000$ include 50 percent of benefits; over $\$ 44,000$ they include 85 percent. "Combined income" is adjusted gross income as reported on tax forms plus nontaxable interest income plus one half of Social Security benefits.
} 
Table 1. Percent of Pre-Retirement Salary Required to Maintain Living Standards, 2008

\begin{tabular}{|l|c|c|}
\hline $\begin{array}{l}\text { Pre- } \\
\text { retirement } \\
\text { earnings }\end{array}$ & $\begin{array}{l}\text { Two }- \\
\text { earner } \\
\text { couples }\end{array}$ & $\begin{array}{l}\text { Single } \\
\text { workers }\end{array}$ \\
\hline$\$ 20,000$ & 94 & 88 \\
\hline$\$ 50,000$ & 81 & 80 \\
\hline$\$ 90,000$ & 78 & 81 \\
\hline
\end{tabular}

Source: Palmer (2008).

The question is how close do households with a state-local worker come to the 80 percent target replacement rate?

\section{Constructing Replacement Rates}

Constructing replacement rates raises a number of issues. ${ }^{8}$ The first question is the relevant measure of pre-retirement earnings. Social Security - the primary source of monthly cash income for today's elderly Americans - replaces a portion of "average indexed monthly earnings" (AIME), which is essentially the 35 highest years of earnings indexed to the present by wage growth. ${ }^{9}$ Employer-sponsored defined benefit plans - the other source of monthly income - typically replace a portion of the worker's annual earnings during the last three or five years of employment, which tend to be the worker's highest earnings with that employer. Thus preretirement income could be defined as: 1) some measure of lifetime earnings; 2) earnings with a particular employer; or 3) earnings just prior to retirement. This study uses earnings just before retirement, defined as the highest five in the last ten years adjusted for inflation, because it provides a measure of the end-of career standard of living that workers seek to maintain in retirement.

A second consideration is defining when "pre-retirement" ends and retirement begins. With the growth of bridge jobs, it is often impossible to define precisely the work/retirement divide. For this reason, this study focuses on the first year that workers start receiving Social

\footnotetext{
${ }^{8}$ The following discussion and basic methodology are derived from earlier research by the Center for Retirement Research at Boston College (Munnell and Soto 2005).

${ }^{9}$ In the case of retirement, the AIME is determined in two steps. First, the worker's annual taxable earnings after 1950 are updated, or indexed, to reflect the general earnings level in the indexing year, which is age 60. Earnings in years after 60 are not indexed but instead are counted at their actual value. A worker's earnings prior to age 60 are indexed by multiplying them by the ratio of the average wage in the national economy for the indexing year to the corresponding average wage figure for the year to be indexed. Second, the AIME is calculated by taking the highest 35 years of wage-indexed earnings between ages 22 and 62 and dividing that total by the number of months in that period.
} 
Security benefits. In the case of couples, retirement is defined as when both members of the household are receiving benefits.

A third consideration is the unit of analysis. Replacement rates have largely been calculated on an individual worker basis, even though the great majority (roughly 80 percent) of Americans enters retirement as part of a married couple household. The general presentation of replacement rates on an individual worker basis no doubt reflects the fact that Social Security and employer pension benefits are based on individual worker earnings. This paper also presents individual replacement rates. But households consume on a joint basis, so the paper calculates replacement rates for couples and single-person households as well.

\section{Replacement Rates for Individuals}

To calculate replacement rates, this paper uses the HRS, which contains detailed information on earnings before retirement and on Social Security and pension benefits as well as 401(k)/IRA balances, and is thus ideal for this study. ${ }^{10}$ The original HRS sample consisted of 12,652 individuals from 7,607 households with respondents 51 to 61 years old in 1992 (born between 1931 and 1941), and their spouses. The survey has been re-administered every two years. The HRS subsequently has expanded the sample dramatically, ${ }^{11}$ but this study uses the original HRS sample and follows this group through the 2008 survey. The final sample consists of 8,900 newly retired workers and 4,469 newly retired households (see Appendix A for derivation of the sample).

This section reports individual Social Security replacement rates for HRS workers and compares them to official Social Security Administration (SSA) replacement rates for new retirees. For comparison purposes, replacement rates are based on AIME. Having verified that the Social Security replacement rates are consistent with reported data, it then turns to constructing replacement rates based on earnings just before retirement (the highest five in the last ten years adjusted for inflation) first for Social Security and then for Social Security and employer-sponsored defined benefit and defined contribution plans. The replacement rates are

\footnotetext{
${ }^{10}$ See Juster and Suzman (1995) for a detailed overview of the survey.

${ }^{11}$ War Babies (born between 1942 and 1947) were added in 1998; Early Boomers (born between 1948 and 1953) were added in 2004; and Mid Boomers (born between 1954 and 1959) were added in 2010. Like the original sample, these three additional cohorts are interviewed every two years.
} 
presented for private sector workers and for those who worked for state-local governments by their tenure in the public sector.

\section{Social Security Benefits Relative to AIME}

To test whether the HRS provides a picture consistent with that reported by SSA, this section replicates the tables provided in the SSA's 2004 Performance and Accountability Report. $^{12}$ This exercise involves looking in various waves of the HRS at individuals age 62 and over and calculating benefits as a percent of AIME in the year when the worker first claims benefits. The specific calculations for the HRS are as follows:

- Retirement age. The retirement age comes from the self-reported year when the respondent first received Social Security Benefits (rassageb from RAND-HRS). For those respondents with missing values, retirement ages are obtained from the retirement year indicator from RAND-HRS (r*retyr). Individuals who retire before age 62 because of disability (radiget) are excluded from the final sample. Early retirees who cannot be identified as disabled are randomly assigned a retirement age based on the pattern of retirement by gender reported by the Social Security Administration. ${ }^{13}$

- $\quad A I M E$, PIA, and Social Security benefit. Social Security earnings are taken from the restricted data set of the HRS Covered Earnings Records for the years 1951-2007. In 2008, earnings are calculated from self-reported data in the HRS and capped at the maximum taxable level. The earnings history is then used to construct the AIME. The Primary Insurance Amount (PIA) and Social Security benefit are calculated using the Social Security benefit formula. ${ }^{14}$

Table 2 presents median earned replacement rates - replacement rates based on the individual's earnings record - of newly retired-worker beneficiaries for the SSA sample and the HRS. ${ }^{15}$ The results are remarkably close. The median replacement rate for the total population in the two samples is in the $42-44$ percent range. ${ }^{16}$ This overall rate is the composite of a median replacement rate of 37 percent for men and about 52 percent for women.

\footnotetext{
${ }^{12}$ The data come from a 1-percent sample of the Continuous Work History Sample supplemented with information from the Master Earnings File for persons retiring in 1999-2003.

${ }^{13}$ U.S. Social Security Administration (2010).

${ }^{14}$ The Social Security benefit calculation for individuals does not account for either spousal or survivor benefits.

${ }^{15}$ The individual observations are weighted by the HRS wave 1 weight to reflect the U.S. population.

${ }^{16}$ This 42 percent should not be confused with the 42 percent reported in the Social Security Trustees Report for the worker with medium scaled earnings retiring at age 65 , because the majority of real-world men and women claim benefits well before the full retirement age.
} 
Table 2. Median Social Security Replacement Rates ${ }^{a}$ of New Retired-Worker Beneficiaries

\begin{tabular}{|c|c|c|c|c|c|c|}
\hline \multirow{2}{*}{ Year } & \multicolumn{2}{|c|}{ Total } & \multicolumn{2}{c|}{ Men } & \multicolumn{2}{c|}{ Women } \\
\cline { 2 - 7 } & SSA $^{\mathrm{b}}$ & HRS & SSA $^{\mathrm{b}}$ & HRS & SSA $^{\mathrm{b}}$ & HRS \\
\hline Before 1999 & & 43.0 & & 36.2 & & 53.4 \\
\hline 1999 & 42.8 & 44.2 & 37.0 & 37.6 & 52.0 & 50.7 \\
\hline 2000 & 42.9 & 44.7 & 37.5 & 38.5 & 52.4 & 52.2 \\
\hline 2001 & 42.6 & 43.3 & 36.7 & 37.6 & 51.8 & 55.5 \\
\hline 2002 & 42.1 & 43.2 & 36.5 & 36.4 & 50.8 & 53.3 \\
\hline
\end{tabular}

a. The replacement rate is calculated as the ratio of the retired worker's benefit based on his own earnings to his average indexed monthly earnings (AIME). The AIME is the worker's highest 35 years of earnings, which have been adjusted for changes in the average wage index to the year of attainment of age 60 .

b. Based on the 1-percent Continuous Work History Sample supplemented with information from the Master Earnings File for persons retiring in 1999-2003.

Sources: Authors' calculations from the University of Michigan, Health and Retirement Study (HRS), 1992-2008; and U.S. Social Security Administration (2004).

\section{Replacement Rates Based on Earnings Prior to Retirement}

Having determined that the Social Security replacement rates based on AIME are consistent with published data, this section shifts the denominator to total earnings just before retirement (the highest five in the last ten years adjusted for inflation). It reports replacement rates first for Social Security and then for Social Security and employer-sponsored defined benefit and defined contribution plans, and presents the results for individuals who spent their entire career in the private sector and those who worked in the state-local sector. For those in the public sector, replacement rates are reported by the percent of career spent in that sector: 1-15 percent, 15-50 percent, and more than 50 percent. ${ }^{17}$ As shown in Figure 1, roughly one third of households and individuals are in the middle group, somewhat more in the short-tenure group, and somewhat fewer in the long-tenure group.

\footnotetext{
${ }^{17}$ For couples with two state-local workers, the household is classified by the tenure of the longest tenure worker.
} 
Figure 1. Distribution of State and Local Workers by Tenure

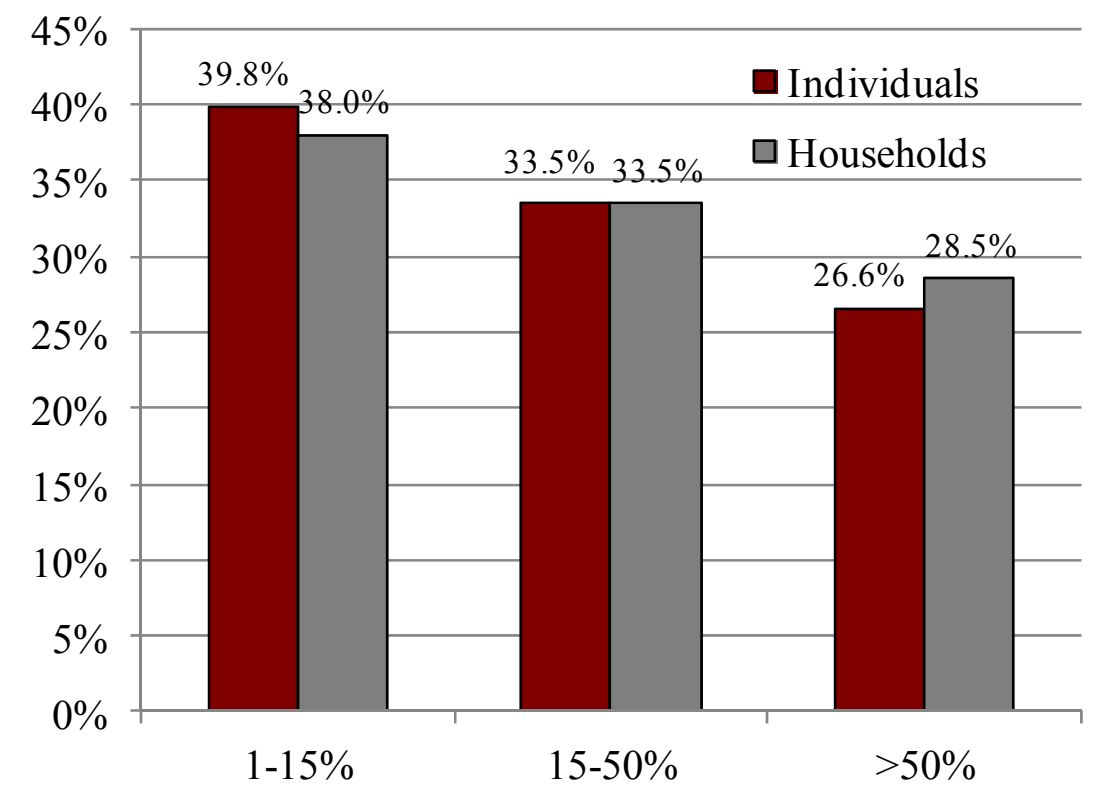

Source: Authors' calculations from the HRS.

Calculating total earnings just prior to retirement requires some adjustments to the restricted data, which contain only the covered earnings records for individual workers between 1951 and 2007. Since earnings are top-coded at the maximum taxable earnings for each year, the calculation of actual career-average earnings for some individuals requires imputations. About 15 percent of the final sample of individuals used in this study required imputations for at least one year of earnings. To impute earnings for those at the maximum taxable earnings, a randomeffects, Tobit regression is applied to all of the available data, with earnings below the cap as the dependent variable. The explanatory variables include age, age squared, categorical variables for gender, college degree and race, and dummies for each decade. For individuals with coded earnings at the cap, their total earnings are imputed using the regression results. The total earnings history is then used to calculate the highest five in the last ten years adjusted for inflation for each individual.

The Social Security replacement rate is simply the benefits reported above divided by the calculated pre-retirement earnings. The results are shown in Table 3 below. Social Security alone provides a median replacement rate for private workers of 29 percent and for state-local workers of 26 percent. 
The next step is to expand the income sources to include income from defined benefit and defined contribution plans. In both cases, income was calculated as the annuitized value of pension wealth. The argument for taking this approach in the case of defined benefit as well as defined contribution plans is that simply reporting the first year benefit would understate the value of state-local defined benefit pensions since these benefits are adjusted annually - at least partially - for inflation. Both defined benefit and defined contribution wealth come from the Peticolas-Steinmeier data posted on the HRS website; these numbers are derived from the restricted pension data provided by the employer. The data are presented at ages 50, 55, 60, 62, and 65 , and we selected the observation closest to the individual's retirement age. ${ }^{18}$ Unfortunately, the wealth data were available only for a portion of our sample. Thus, defined benefit pension wealth had to be calculated based on reported benefits using the same assumptions about inflation and asset returns as Peticolas-Steinmeier. ${ }^{19}$ For comparability with Peticolas-Steinmeier, the calculations were made for ages 50, 55, 60, 62, and 65, and the value closest to the retirement age was selected. ${ }^{20}$

Individuals were identified as having a defined contribution plan in one of two ways either they have Peticolas-Steinmeier defined contribution wealth or they indicated in the first (1992) wave that they were covered by an employer-sponsored defined contribution plan. For those without Peticolas-Steinmeier defined contribution wealth, IRA balances are set equal to pension wealth because most of the assets in these accounts are rollovers from 401(k) plans and the earnings on those rollovers. ${ }^{21}$ For those with Peticolas-Steinmeier wealth, IRA balances are combined with defined contribution assets. For those without pension coverage, IRA assets are included in total financial wealth. ${ }^{22}$

\footnotetext{
${ }^{18}$ A small fraction (about 2 percent) of respondents in the HRS sample indicated having a pension plan with both defined benefit and defined contribution characteristics. Data on defined contribution assets in these "combined" plans were often not available, so they are grouped together with defined benefit plans.

${ }^{19}$ The assumptions for the wealth calculations were inflation of 2.8 percent and real returns of 2.3 percent for consistency with the Social Security calculations. The Peticolas-Steinmeier wealth variables assume a 4-percent inflation rate, so those figures were adjusted. See Appendix B for details.

${ }^{20}$ The resulting numbers for both defined contribution and defined benefit plans are comparable to those reported by Gustman and Steinmeier (1999).

${ }^{21} \mathrm{~A}$ recent study found that 80 percent of $401(\mathrm{k})$ assets are rolled over into IRA accounts within five years of the employee leaving work. For this reason, we assume that the IRA variable captures the majority of $401(\mathrm{k})$ assets. Increasingly, of course, IRA accumulations will also include rollovers from defined benefit and cash balance plans (Utkus and Young 2010).

${ }^{22}$ Median defined contribution wealth for those with coverage is $\$ 67,000$ (excluding IRA assets) and median defined benefit wealth is $\$ 97,000$. These results are fully consistent with those from other studies.
} 
The next step is to derive a stream of annual income by applying annuity factors to the defined benefit and defined contribution wealth. The annuity factors vary by gender and marital status. In addition, an 18-percent increase in cost due to adverse selection, marketing, and other factors is applied to annuities purchased in the private market. ${ }^{23}$ Married men are assumed to opt for a joint-and-survivor annuity that provides 50 percent of the benefit to the surviving spouse. (The particular annuity factors applied are reported in Appendix B.) The replacement rates reported in the paper are based on nominal annuities, under which the purchasing power of benefits will decline over time; replacement rates based on real (inflation-adjusted) annuities, which produce lower initial levels of replacement, are reported in Appendix C.

Table 3 shows Social Security benefits at the individual's retirement age relative to the expanded earnings base and the impact of income from employer-sponsored plans on the replacement rates of single individuals for private sector and state-local workers. Adding the annuitized value of defined benefit and defined contribution wealth brings the median replacement rate to 42 percent for private sector workers and to 54 percent for workers with some state-local employment. For those with state-local government experience, the replacement rate increases with the percent of career spent in the public sector. ${ }^{24}$ It ranges from 47 percent for those with less than 15 percent of their career in state-local government to 70 percent for those with more than 50 percent of their career as a state-local employee.

\footnotetext{
${ }^{23}$ Premium loads on annuities vary with annuity type and with the age of purchase. They also vary between companies and over time, and are somewhat sensitive to the choice of interest rate used to calculate expected present values. Mitchell et al. (1999), Table 3, report loads that are typically on the order of 18 percent.

${ }^{24}$ The HRS reports the year that the individual began work in the state-local sector and the year that state-local employment ended. Subtracting one year from the other provides the total years spent in the state-local sector; those years are then divided by the total length of the individual's career, as reported in the RAND data.
} 
Table 3. Median Replacement Rates ${ }^{a}$ for Individual Workers by Employment History

\begin{tabular}{|l|l|l|l|l|l|l|l|}
\hline \multirow{2}{*}{$\begin{array}{l}\text { Retirement } \\
\text { income source }\end{array}$} & All & $\begin{array}{l}\text { Without } \\
\text { pensions }\end{array}$ & $\begin{array}{l}\text { With } \\
\text { pensions }\end{array}$ & All & \multicolumn{3}{|c|}{$\begin{array}{l}\text { Percent of career spent in } \\
\text { state-local sector }\end{array}$} \\
\cline { 2 - 8 } & & & & & $1-15 \%$ & $15-50 \%$ & $>50 \%$ \\
\hline Social Security & 29.2 & 32.4 & 27.6 & 26.4 & 27.8 & 26.5 & 23.4 \\
\hline $\begin{array}{l}\text { Social Security } \\
\text { + pensions }\end{array}$ & 41.7 & 32.4 & 49.1 & 53.6 & 46.6 & 53.3 & 69.8 \\
\hline $\begin{array}{l}\text { Addendum: } \\
\text { Percent of } \\
\text { sample }\end{array}$ & 76 & 35 & 41 & 24 & 10 & 8 & 6 \\
\hline
\end{tabular}

a. The denominator is the individuals' top five years of earnings indexed for inflation.

b. For those with pension coverage, IRA assets are included in defined contribution wealth; for those without pension coverage, IRA assets are classified as part of financial assets.

Source: Authors' estimates from the HRS.

\section{Household Replacement Rates}

This section moves the analysis forward in two steps. First, the HRS population is reassembled into households, and Social Security replacement rates based on AIME are estimated for the household unit to ensure that they are consistent with published benchmarks. Second, the expanded earnings already calculated for individual workers are combined into household numbers, providing the base for calculating the highest five years of earnings in the last ten years; then household Social Security benefits and pension benefits are divided by earnings to produce replacements rates.

\section{Social Security Benefits Relative to AIME}

The earned replacement rates for individuals provided in SSA's Performance and Accountability Report offer a benchmark against which to assess the reasonableness of the household numbers. For example, SSA shows the median male earned replacement rate is about 37 percent and the median female earned replacement rate is about 52 percent. The average for single people, assuming that single people have similar earnings histories as married people, should be a weighted average of the two. Since women account for 70 percent of single workers covered by Social Security, a first approximation of the combined replacement rate for single workers should be 47 percent.

Couples consist of two types - those with one worker where the spouse has an AIME of zero and those where both spouses work and both have a positive AIME. Again assuming that 
single people have similar earnings histories as married people, for couples in which the wife has no earnings record of her own, one would expect a replacement rate of 150 percent of 37 percent or 55.5 percent. In couples where both spouses have an earnings record, two adjustments occur. First, the wife's earnings record goes into the denominator. Second, the wife's benefit, which is the greater of 50 percent of her husband's benefit or the benefit based on her own earnings record, goes into the numerator. With the information that 1) the median earned replacement rate for men is 37 percent and for women 52 percent; and 2) according to the HRS the median ratio of wife's to husband's AIME is 48 percent, it is possible to approximate the replacement rate for the median two-earner couple. ${ }^{25}$ That is, for a two-earner median couple the expected replacement rate is equal to:

$$
\begin{aligned}
& \frac{B E N(\text { male })+B E N(\text { female })}{A I M E(\text { male })+A I M E(\text { female })}=\frac{B E N(\text { male })+\max (0.5 * B E N(\text { male }), B E N(\text { female }))}{A I M E(\text { male })+0.48 * A I M E(\text { male })} \\
& \frac{0.37 * \operatorname{AIME}(\text { male })+\max (0.5 * 0.37 \text { AIME }(\text { male }), 0.52 * 0.48 \text { AIME }(\text { male }))}{1.48 \text { AIME }(\text { male })} \\
& =\frac{0.37 \text { AIME }(\text { male })+\max (0.19 A I M E(\text { male }), 0.25 A I M E(\text { male }))}{1.48 A I M E(\text { male })} \\
& =\frac{0.37 \text { AIME }(\text { male })+0.25 A I M E(\text { male })}{1.48 A I M E(\text { male })}
\end{aligned}
$$

$\frac{0.62 A I M E(\text { male })}{1.48 \text { AIME }(\text { male })}=41.9$ percent

The next step is to calculate actual replacement rates for households using the HRS. This step involves aggregating individual information into a household format. In the case of singleperson households, benefits are simply the amount received in the year the individual retires.

For couples, benefits are presented for the first year in which both members of the household are retired. In the case where both members of the couple are already retired, the procedure is to adjust the AIME and PIA for each spouse for inflation in order to report them for a common year. In the case where only one spouse is retired, the working spouse - generally the woman is randomly assigned a retirement age based on the female pattern of retirement. Since the

\footnotetext{
${ }^{25}$ The following exercise assumes that the median man is married to the median woman. This is a strong assumption, but the equation is used only as a gauge for expected outcomes.
} 
replacement rate is calculated on the assumption that both spouses are retired, earnings are eliminated from the numerator of the replacement rate calculation. Eliminating earnings presents a more realistic picture of the income replacement the couple will enjoy over their retirement span. The derivation of the retirement age and Social Security AIME, PIA, and benefit are described above.

Replacement rates for households as calculated from the HRS data and as predicted from SSA's Performance and Accountability Report are shown in Table 4. The two patterns are remarkably consistent.

Table 4. Median Social Security Replacement Rates for HRS Households

\begin{tabular}{|c|c|c|r|}
\hline Household type & \multicolumn{2}{|c|}{ Replacement rate } & \multirow{2}{*}{$\begin{array}{c}\text { Number of } \\
\text { HRS } \\
\text { observations }\end{array}$} \\
\cline { 2 - 3 } & $\begin{array}{c}\text { Predicted } \\
\text { from SSA } \\
\text { study }\end{array}$ & HRS & 2,961 \\
\hline Couples & 44.6 & 44.8 & 562 \\
\hline Spouse AIME $=0$ & 55.5 & 51.8 & 2,399 \\
\hline Spouse AIME $>0$ & 41.5 & 44.1 & 1,479 \\
\hline Single & 47.3 & 42.7 & 431 \\
\hline Men & 37.0 & 37.9 & 1,048 \\
\hline Women & 52.0 & 46.2 & 4,440 \\
\hline All & 45.5 & 44.4 & \multirow{2}{*}{. } \\
\hline
\end{tabular}

Source: Authors' predictions based on results of SSA's Performance and Accountability Report (2004) and calculations from the HRS.

\section{Replacement Rates Based on Earnings Prior to Retirement}

Having determined that the Social Security replacement rates based on AIME for households are consistent with published data, this section shifts the denominator to earnings just before retirement (the highest five in the last ten years adjusted for inflation). The household earnings data are based on the individual earnings data described in the previous section.

Household replacement rates from Social Security are determined by dividing household Social Security benefits calculated at the relevant retirement age by the expanded earnings measure. Household income from the annuitized value of defined benefit and defined contribution assets (including IRAs for those with defined contribution coverage) is summed for individuals in the households. As before, household replacement rates are estimated at the first year in which both members of the household are retired. This calculation is done by estimating the annuity value for defined benefit and defined contribution pensions for each member of the 
household starting at his or her retirement age and then projecting this value to the year in which the second member of the household retires. Dividing these values by the expanded earnings measure produces pension replacement rates.

Replacement rates for households by employment status are shown in Table 5. All the replacement rates are slightly higher than those shown for individuals in Table 3, but the pattern remains the same. Replacement rates are higher in the state-local sector than in the private sector, primarily because almost 40 percent of private sector households have no employersponsored pension benefits. Within the public sector, replacement rates increase with tenure from 48 percent for households with a short-tenured employee to 72 percent for those with a long-tenured worker. Again, median replacement rates do not reach the 80 percent target for most households with state-local employment.

Table 5. Median Replacement Rates ${ }^{a}$ for Households by Employment History

\begin{tabular}{|l|l|l|l|l|l|l|l|}
\hline \multirow{2}{*}{$\begin{array}{l}\text { Retirement } \\
\text { income source }\end{array}$} & All & $\begin{array}{l}\text { Without } \\
\text { pensions }\end{array}$ & $\begin{array}{l}\text { With } \\
\text { pensions }\end{array}$ & All & \multicolumn{3}{|c|}{$\begin{array}{c}\text { Percent of career spent in } \\
\text { State-local sector }\end{array}$} \\
\cline { 3 - 8 } & & & & $1-15 \%$ & $15-50 \%$ & $>50 \%$ \\
\hline Social Security & 32.0 & 35.7 & 30.9 & 29.3 & 29.7 & 29.4 & 28.3 \\
\hline $\begin{array}{l}\text { Social Security } \\
\text { + pensions }\end{array}$ & 46.9 & 35.7 & 52.0 & 57.4 & 47.6 & 57.0 & 71.8 \\
\hline $\begin{array}{l}\text { Addendum: } \\
\text { Percent of } \\
\text { sample }\end{array}$ & 67 & 24 & 43 & 33 & 13 & 11 & 9 \\
\hline
\end{tabular}

a. The denominator is the individuals' top five years of earnings in the last ten years indexed for inflation. b. For those with pension coverage, IRA assets are included in defined contribution wealth; for those without pension coverage, IRA assets are classified as part of financial assets.

Source: Authors' estimates from the HRS.

\section{The Impact of Non-Pension Financial Assets}

The final exercise with the HRS explores the impact of non-pension financial assets on replacement rates. Financial wealth comes from the RAND subset of the HRS and includes stocks, bonds, savings and checking accounts, certificates of deposit, and any other account, minus non-housing debt.

In order to make the calculations economically meaningful, the definition of preretirement income needs to be expanded to include a measure of pre-retirement income from financial assets. Non-pension financial wealth was not annuitized; rather income was derived by applying a nominal return to asset values. The nominal return was 5.1 percent $(2.3$ percent real 
return and inflation of 2.8 percent), consistent with the assumptions used throughout the analysis. The results are shown in Table 6. Adding income from financial assets closes the gap somewhat, but still leaves most state-local households short of the 80-percent target.

Table 6. Median Replacement Rates ${ }^{a}$ for Households, Including Financial Assets, by Employment History

\begin{tabular}{|l|l|l|l|l|l|l|l|}
\hline \multirow{2}{*}{$\begin{array}{l}\text { Retirement } \\
\text { income source }\end{array}$} & \multicolumn{3}{|c|}{ Private sector } & \multicolumn{4}{c|}{ State-local sector } \\
\cline { 2 - 8 } & All & $\begin{array}{l}\text { Without } \\
\text { pensions }\end{array}$ & $\begin{array}{l}\text { With } \\
\text { pensions }\end{array}$ & All & \multicolumn{2}{c|}{$\begin{array}{c}\text { Percent of career spent in } \\
\text { State-local sector }\end{array}$} \\
\cline { 5 - 8 } & & & & & $1-15 \%$ & $15-50 \%$ & $>50 \%$ \\
\hline Social Security & 30.3 & 34.0 & 29.1 & 27.1 & 27.8 & 27.3 & 25.8 \\
\hline $\begin{array}{l}\text { Social Security } \\
+ \text { pensions }\end{array}$ & 44.8 & 34.0 & 50.0 & 53.1 & 43.4 & 54.2 & 67.5 \\
\hline $\begin{array}{l}\text { Social Security } \\
+ \text { pensions } \\
\text { Financial assets }\end{array}$ & 51.0 & 40.5 & 55.6 & 60.2 & 50.9 & 61.3 & 72.7 \\
\hline
\end{tabular}

a. The denominator is the individuals' top five years of earnings in the last ten years indexed for inflation plus income from financial assets.

b. For those with pension coverage, IRA assets are included in defined contribution wealth; for those without pension coverage, IRA assets are classified as part of financial assets.

c. The real return on financial assets is assumed to be 2.3 percent.

Source: Authors' estimates from the HRS.

\section{Insights from the Actuarial Data}

To provide some insight on why actual replacement rates for workers with state-local experience are lower than generally thought, this section provides evidence on benefit status and replacement rates for those leaving some of the nation's largest public pension systems in 2010. These systems are CalPERS, Connecticut SERS, Florida RS, Kentucky TRS, New Jersey PERS, New Jersey TRS, Ohio Schools, Ohio Teachers, Texas ERS, Texas TRS, and Wisconsin RS. Together, these plans represent 18 percent of the nation's liabilities and 22 percent of the members.

First, using each system's actuarial valuation, it is possible to generate the population of those with at least one year of service who leave public sector employment in a given year, either by quitting before vesting, quitting with deferred benefits, or retiring. The valuations contain data on the demographics of active employees (sex, age, tenure, and salary) and on the probability of retirement - when an employee leaves active service and immediately begins receiving benefits - and of separation - when an employee leaves state-local employment but 
does not immediately claim benefits because they are not eligible or did not vest. Applying the probabilities of retirement and separation to the population of active members according to their sex, age, and tenure yields the population of those who left state-local active service. Those who leave with under five years of tenure are deemed as not vested. Figure 2 presents the distribution by tenure and benefit status for the 11 large plans identified above.

Figure 2. Distribution of Leavers in Eleven Large Plans by Tenure and Benefit Status, 2011

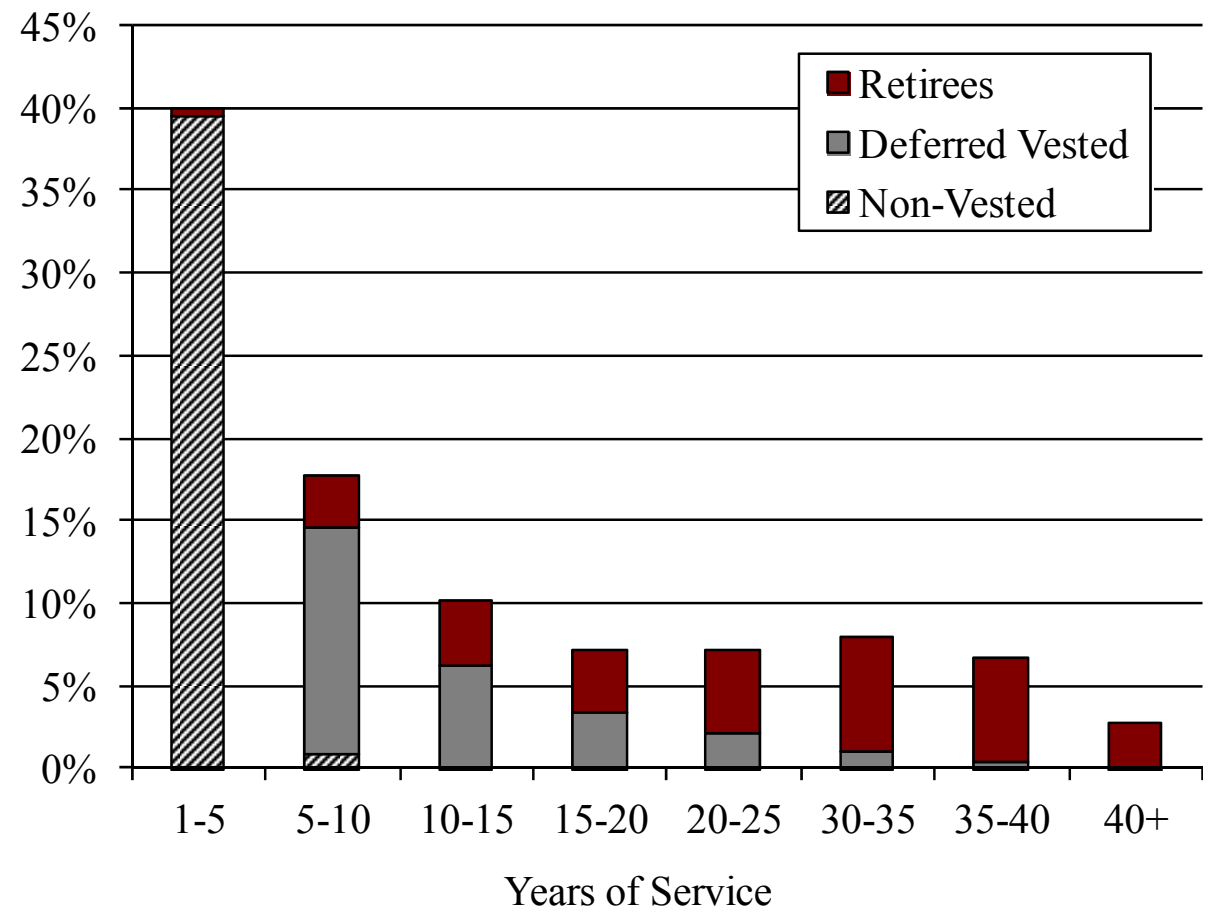

Note: New Jersey PERS and TRS are different from most plans. For most plans, the vesting period is five years. For New Jersey PERS and TRS, the vesting requirement depends on the type of retirement. Those who leave service before the normal retirement age must have ten years of tenure in order to claim a deferred benefit. Those who retire directly from active service at the normal retirement age have no minimum tenure requirement. These provisions result in a small number of retirees with less than five years of tenure, and some non-vested separators with over five years of tenure.

Source: Authors' estimates from various actuarial reports.

Of those who leave with at least one year of service, only 32 percent claim benefits immediately, 27 percent will receive a deferred benefit based on their earnings at termination, and 40 percent leave without any promise of future benefits (see Figure 3 ). ${ }^{26}$

\footnotetext{
${ }^{26}$ This pattern is similar to that found by the State of Maine Unified Retirement Plan Task Force (2010).
} 
Figure 3. Percent of Leavers in Eleven Large Plans by Benefit Status

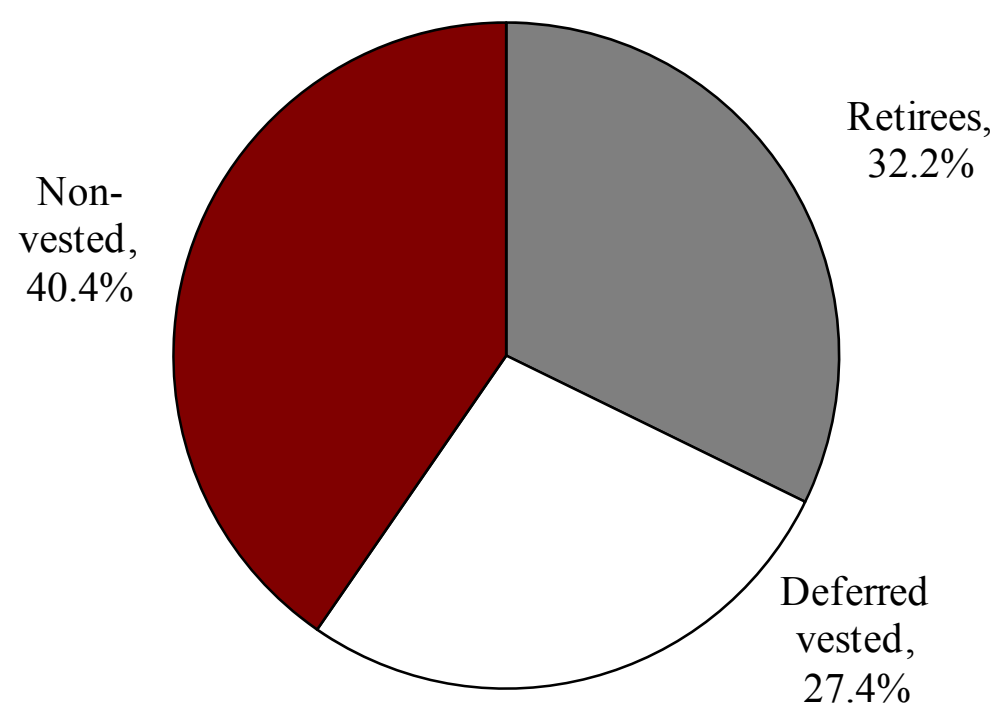

Source: Authors' calculations from various actuarial reports.

The next step is to estimate replacement rates for those who have left state-local employment. For this exercise, the focus is on a subset of plans where workers are covered by Social Security - CalPERS, New Jersey PERS, New Jersey TRS, Texas ERS, and Wisconsin RS. $^{27}$ The replacement rate is defined as the annual benefit payment divided by the employee's salary at retirement. In the case of the non-vested, the answer is easy - the replacement rate is zero. $^{28}$ For those who retire immediately, the calculation is straightforward: the annual benefit divided by the last year's salary. The annual benefit is calculated by applying the benefit formula to the relevant earnings base, usually the last three years.

For the deferred vested, the benefit calculation is also straightforward: the benefit formula applied to the earnings base in the three years before separation. In order to understand the importance of these deferred benefits at retirement, however, it is necessary to compare them with earnings at that time. This calculation requires some assumptions. First, we assume that the separator will claim his benefit at the system's normal retirement age, generally around age

${ }^{27}$ Connecticut SERS, and Florida RS are omitted due to insufficient data.

${ }^{28}$ Unlike private sector 401 (k) plans, most state and local pensions feature mandatory participation. State-local employees who terminate without vesting in the plan receive a refund on their contributions with a modest rate of interest. Although these refunds are likely quite small, they do have the opportunity to grow over time. 
60. Second, we apply each system's salary growth assumption to estimate the separator's salary at that age. Since the average age of those with deferred benefits is 44 (see Table 7), the value of these benefits is seriously eroded by inflation and salary growth.

Table 7. Age and Tenure of Leavers by Benefit Status, 2011

\begin{tabular}{|l|r|r|r|}
\hline Characteristics & Non-Vested & Deferred Benefit & Retired \\
\hline Average age & 37.7 & 44.3 & 61.0 \\
\hline Average tenure & 2.2 & 11.7 & 22.8 \\
\hline
\end{tabular}

Source: Authors' estimates from various actuarial reports.

The average replacement rates for those with non-vested, deferred, and immediate benefits by tenure are presented in Figure 4. Those who leave without vesting usually receive only a refund of their contributions with modest interest and no benefits from the plan. Those who leave mid-career receive deferred benefits that amount to less than 10 percent of earnings at retirement. And those who claim immediately around age 60 receive benefits equal to 49 percent of final earnings. These differentials are roughly consistent with the patterns that emerge from the HRS data. 
Figure 4. Replacement Rates for State-Local Workers by Benefit Status

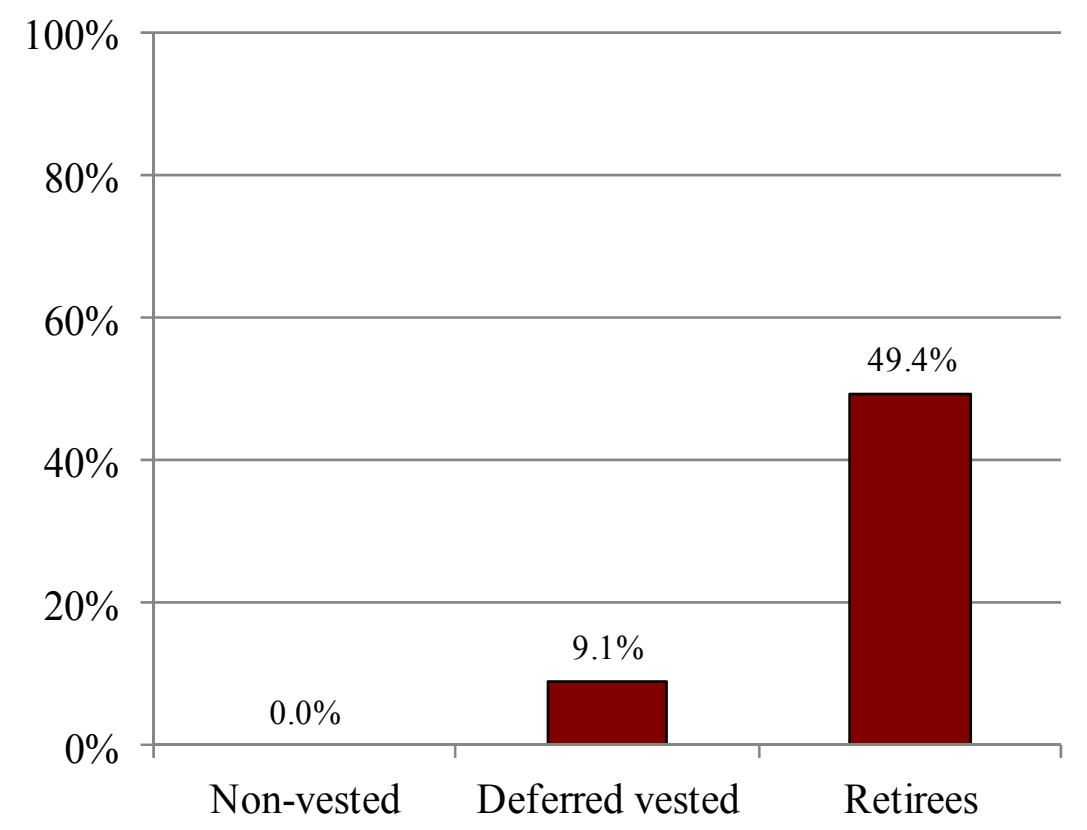

Source: Authors' estimates from various actuarial reports.

\section{Conclusion}

This study addresses the widespread perception that state-local workers have more than adequate income in retirement. The perception is consistent with multiplying the 2-percent benefit factor in most plan formulae by a 35- to 40 -year career and adding a Social Security benefit. But this calculation assumes that individuals spend enough of their career in the public sector to produce such a retirement outcome. Analysis of replacement rates of state-local workers in the HRS suggest that households with even long-career state-local employees fall short of the target replacement rate of 80 percent of pre-retirement earnings.

The explanation for these lower-than-anticipated replacement rates is twofold. First, as the actuarial data show, only 32 percent of workers who leave state-local employment each year claim an immediate benefit. These individuals have more than 20 years of service on average and receive a benefit equal to 49 percent of their pre-retirement earnings. But another 27 percent leave state-local employment with a deferred benefit based on their earnings at termination, which will decline in value between termination and claiming as wages and prices rise, so it will amount to less than 10 percent of their projected earnings at retirement. And 40 percent leave without any promise of future benefits. Second, most households with a state-local worker 
contain a person employed in the private sector, and replacement rates for private sector workers are considerably lower since many end up with nothing more than Social Security. 


\section{References}

Banks, J., Blundell, R. and S. Tanner, S. 1998. "Is There a Retirement-Savings Puzzle?" American Economic Review 88(4): 769-88.

Bernheim, D., Skinner, J. and S. Weinberg. 2001. "What Accounts for the Variation in Retirement Wealth among US Households?" American Economic Review 91(4): 832-57.

Beshears, John, James J. Choi, David Laibson, and Brigitte C. Madrian. 2011. "Behavioral Economics Perspectives on Public Sector Pension Plans.” Working Paper 16728. Cambridge, MA: National Bureau of Economic Research.

Engen, Eric, William Gale and Cori Uccello. 1999. "The Adequacy of Retirement Saving." Brookings Papers on Economic Activity 2: 65-165.

Gustman, Alan and Thomas Steinmeier. 1999. "Effects of Pensions on Savings: Analysis with Data from the Health and Retirement Study." Carnegie-Rochester Conference Series on Public Policy 50(June): P271-324.

Hurd, Michael and Susann Rohwedder. 2003. "The Retirement Consumption Puzzle: Anticipated and Actual Declines in Spending at Retirement." Working Paper 9586. Cambridge, MA: National Bureau of Economic Research.

Juster, F. Thomas and Richard Suzman. 1995. "An Overview of the Health and Retirement Study." Journal of Human Resources 30(Supplement): S7-S56.

Mitchell, Olivia S., James M. Poterba, Mark J. Warshawsky, and Jeffrey R. Brown. 1999. "New Evidence on the Money's Worth of Individual Annuities." American Economic Review 89(5): 1299-1318.

Munnell, Alicia H. and Mauricio Soto. 2005. "What Replacement Rates Do Households Actually Experience in Retirement?” Working Paper 2005-10. Chestnut Hill, MA: Center for Retirement Research at Boston College.

Munnell, Alicia H., Jean-Pierre Aubry, Josh Hurwitz, and Laura Quinby. 2011a. "A Role for Defined Contribution Plans in the Public Sector." Issue in Brief SLP-16. Chestnut Hill, MA: Center for Retirement Research at Boston College.

Munnell, Alicia H., Jean-Pierre Aubry, Josh Hurwitz, and Laura Quinby. 2011b. "Comparing Compensation: State-Local Versus Private Sector Workers." Issue in Brief SLP-20. Chestnut Hill, MA: Center for Retirement Research at Boston College.

Palmer, Bruce A. 2008. “2008 GSU/AON RETIRE Project Report.” Research Report Series No. 08-1 (June). Atlanta, GA: J. Mack Robinson College of Business, Georgia State University. 
Public Plans Database. 2009-2011. Center for Retirement Research at Boston College and Center for State and Local Government Excellence.

Scholz, John Karl, Ananth Seshadri, and Surachai Khitatrakun. 2004. "Are Americans Saving 'Optimally' for Retirement?” Working Paper 10260. Cambridge, MA: National Bureau of Economic Research.

State of Maine Unified Retirement Plan Task Force. 2010. Task Force Study and Report: Maine State Employee and Teacher Unified Retirement Plan. Augusta, ME.

University of Michigan. Health and Retirement Study, 1992-2008. Ann Arbor, MI.

U.S. Social Security Administration. 2004. Performance and Accountability Report, FY 2004. Washington, DC.

U.S. Social Security Administration. 2010. Annual Statistical Supplement, FY 2010. Washington, DC.

USA Today. 2007. "Pension Gap Divides Public and Private Workers.” (February 21).

Utkus, Stephen P., and Jean A. Young. 2010. "Distribution Decisions among RetirementAge Defined Contribution Plan Participants." Vanguard Research. Valley Forge, PA: The Vanguard Group, Inc. 


\section{Appendix A \\ Description of HRS Data Used in the Analysis}

\section{Derivation of Individual Sample}

HRS-1992-RAND Sample

- unmatched individuals

13,482

Sample size

10,755

—Weights $<0$

414

These are individuals who married HRS wave

1 respondents after wave 1 , not to be used in wave 1 analysis.

Sample size

10,341

—Earnings missing before age $61 \quad 338$

The HRS restricted SS earnings data are used up to 1991. Earnings after that are from self-reported data. Imputations 1) If earnings are missing, put zeros if individuals report no work; 2) if missing in one year, but greater than zero in the adjacent years, use the average of adjacent years; 3) Zeros if last year reported working is less than the missing year. 4) Assign -10 if we don't observe the individual anymore (death, drop out of sample), 5) Impute earnings for ages 62,63 and 64, taking age 61 earnings and keeping a constant dollar earnings.

Sample size

10,003

-Missing retirement age 1,326 (These are imputed)

For retirement age, RAND data include a variable for the year individuals first receive Social Security (rassageb). Imputations: 1) from rassageb there are about 2,494 missing values. For these individuals, we use the RAND retirement year indicator ( $\mathrm{r}^{*}$ retyr) to impute their retirement age. 2) Many have rassageb values less than 62, which would indicate disability. To correct some of these, radiget codes 0 if individuals never received SSI or disability benefits. For those with radiget $=0$ and rassage $b 62$, retirement age is increased to 62 .

-Imputation.

For those with missing retirement age, we impute the retirement age by randomly assign a retirement age following Social Security age of first receipt of benefits, using the different probabilities available for males and females. (See Table 2).

Sample size

10,003

-Retirement age $<62 \quad 1,103$

These are individuals that, after all the imputations have been done, still have retirement age less than 62, and we cannot say that they are not receiving disability.

Individual data sample size (total)

8,900 


\section{Derivation of Household Sample}

HRS-1992-RAND Sample

-Not in the individual Sample

Sample size

-At least one HH member with missing info 1,457

Sample size

4,469

Couples

2,974

Singles

1,495

\section{Comparison of Rand Data and Sample Characteristics}

Table A-1. Individuals (weighted mean values)

\begin{tabular}{|l|c|c|}
\hline Category & Rand & Paper Sample \\
\hline Number of observations & 13,482 & 8,900 \\
\hline Males: & $47.6 \%$ & $46.4 \%$ \\
\hline Females & $52.4 \%$ & $53.6 \%$ \\
\hline White/Caucasian & $86.9 \%$ & $89.0 \%$ \\
\hline Black/African-American & $10.4 \%$ & $8.6 \%$ \\
\hline Currently married individuals & $74.4 \%$ & $77.2 \%$ \\
\hline Currently married or partnered & $76.8 \%$ & $79.4 \%$ \\
\hline Earnings wave 1 & $\$ 21,968$ & $\$ 23,265$ \\
\hline Earnings wave 2 & $\$ 20,973$ & $\$ 22,704$ \\
\hline Earnings wave 3 & $\$ 18,203$ & $\$ 19,583$ \\
\hline Earnings wave 4 & $\$ 16,658$ & $\$ 18,254$ \\
\hline Earnings wave 5 & $\$ 14,113$ & $\$ 15,143$ \\
\hline Earnings wave 6 & $\$ 11,798$ & $\$ 12,532$ \\
\hline Earnings wave 7 & $\$ 9,370$ & $\$ 9,843$ \\
\hline Earnings wave 8 & $\$ 6,871$ & $\$ 7,197$ \\
\hline Earnings wave 9 & $\$ 6,029$ & $\$ 6,190$ \\
\hline Non-housing financial wealth wave1 & $\$ 53,448$ & $\$ 56,709$ \\
\hline
\end{tabular}

Source: Authors' tabulations from HRS (1992-2008). 
Table A-2. Household (weighted mean values)

\begin{tabular}{|l|c|c|}
\hline Category & Rand & Paper Sample \\
\hline Number of households & $7,357^{29}$ & 4,469 \\
\hline Couples & 4,984 & 2,974 \\
\hline Singles & 2,373 & 1,495 \\
\hline $\begin{array}{l}\text { Married households as a percent of } \\
\text { total }\end{array}$ & $67 \%$ & $67 \%$ \\
\hline Couples' financial data (wave 1) & & \\
\hline Household earnings & $\$ 41,818$ & $\$ 41,521$ \\
\hline Non-housing financial wealth & $\$ 59,137$ & $\$ 65,357$ \\
\hline Singles' financial data (wave 1) & & \\
\hline Household earnings & $\$ 18,247$ & $\$ 25,088$ \\
\hline Non-housing financial wealth & $\$ 30,268$ & $\$ 32,630$ \\
\hline
\end{tabular}

Source: Authors' tabulations from HRS (1992-2008).

${ }^{29} 291$ households are dropped due to missing information. 


\section{Appendix B \\ Derivation of Pension Wealth and Annuity Factors}

The following discussion explains how pension wealth is calculated in the Health and Retirement Study to supplement the numbers provided by Peticolas-Steinmeier. It also explains the annuity factors used to convert wealth back into a flow.

Pension wealth. As Peticolas-Steinmeier wealth values are unavailable for a significant portion of the sample, the missing values are estimated from self-reported data. The annual benefit is the first amount ever received by an individual as reported by RAND.

The basic formulae for calculating the net present value of pension wealth are:

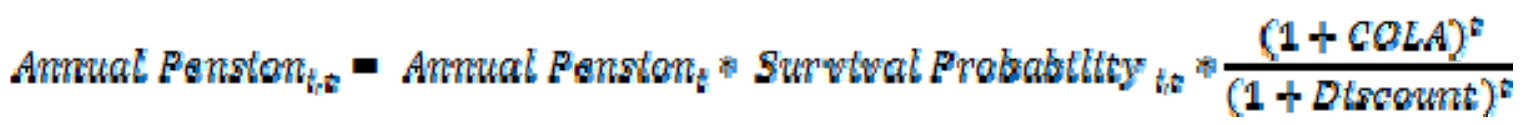

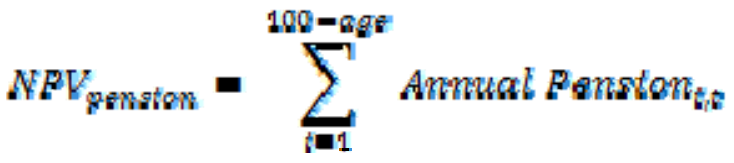

Where $t$ represents years following retirement, and Survival Probability equals the compound probability of living to another year given the respondent's starting age, and is based on Social Security life tables. COLA is the cost-of-living adjustment. The HRS asks whether pensions at the current job receive a COLA. If the variable is missing, we assume that state-local workers receive a COLA, and that private sector workers do not. We are also obliged to make an assumption about the level of the COLA; we chose 1.5 percent based on the average COLA in the Public Plans Database. ${ }^{30}$ The discount rate is set to 5.1 percent -2.3 percent real return on assets and 2.8 percent inflation.

The basic equation is complicated by the fact that some pensions are straight life annuity whereas others are joint-and-survivor. We assume that all married men choose joint-andsurvivor benefits, while married women do not. The surviving spouse's benefit is assumed to be 50 percent of the worker's.

Annuitize pension wealth. To turn the stock of wealth into an annual flow, we divide wealth by an annuity factor (see Table B1):

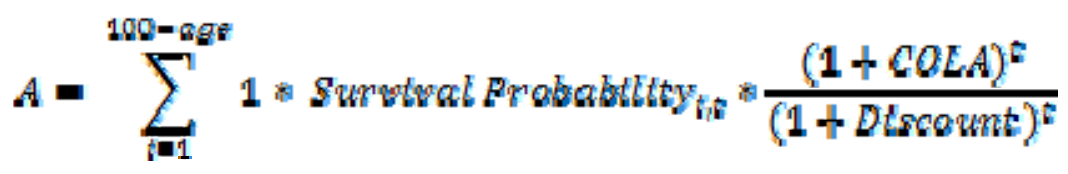

${ }^{30}$ Public Plans Database (2009). 


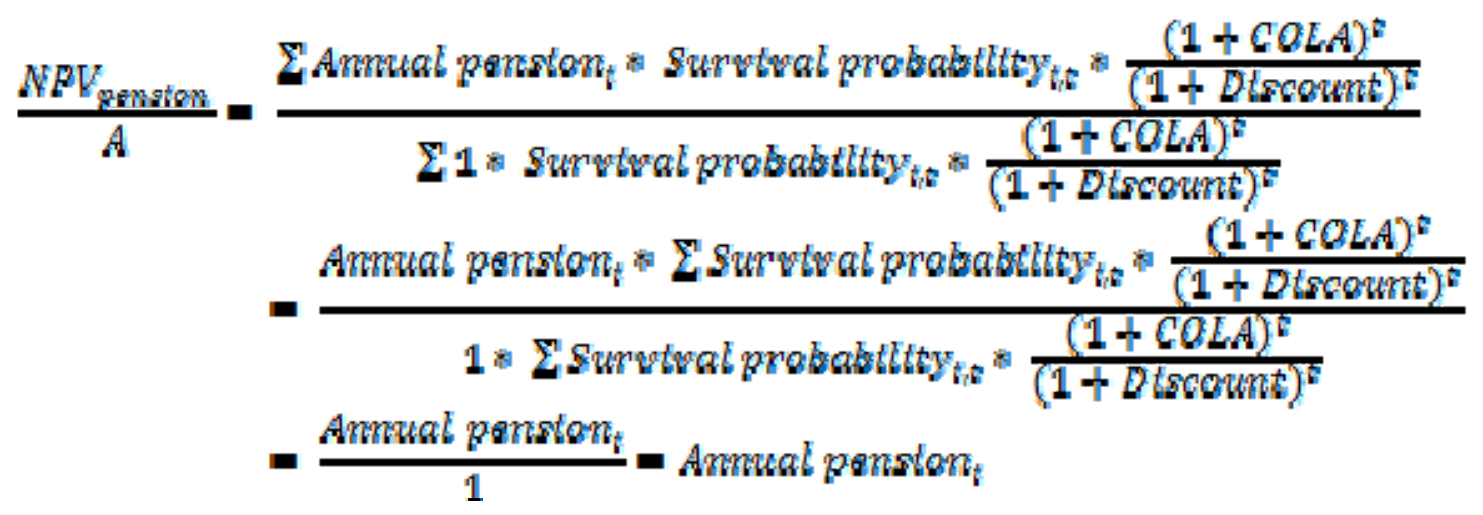

The baseline scenario presented in the paper assumes a nominal annuity with no inflation protection. Thus, the following discussion also focuses on nominal annuities.

A 4-percent inflation assumption built into the the Peticolas-Steinmeier wealth values complicates the basic annuity framework. A more accurate assumption should reflect the longrun inflation assumption made by Social Security, or 2.8 percent in 2011.

In the private sector, pensions generally do not receive a COLA, so Peticolas-Steinmeier would have discounted these pensions using a nominal 6.3 percent rate. Thus, the applicable annuity factor for these pensions is:

$A_{\mathrm{g}}=\sum 1 *$ Surwtral probabtity $y_{t: 2} * \frac{(1+0)^{2}}{(1+0,063)^{2}}$

Unrealistically high inflation is completely offset by the high nominal discount rate.

In the state and local sector, the COLA is typically capped at half of inflation. Because the COLA is capped, the "real" annuity does not actually keep pace with inflation. In fact, the value of the annuity decreases by 2 percent per year in real terms (4-percent inflation minus the 2percent COLA equals 2-percent real depreciation). As a result, the applicable annuity factor for the state and local sector in a world with 4-percent inflation is:

$A_{s l}=\sum 1 *$ Swrvivalprobabtity $y_{t:} * \frac{(1 \mid 0.04)^{t}}{(1+0.063)^{t}} * \frac{1}{1.02^{2}}$

However, we prefer to observe a world in which inflation is only 2.8 percent per year.

Combined with an assumed 2.3-percent real return, this implies a nominal discount rate of 5.1 percent. For comparability with Munnell et al. (2011b) the COLA is set at 1.5 percent (slightly higher than half of inflation). The rate of depreciation of the annuity under this scenario is only 1.3 percent. The new annuity factor becomes:

$A_{g h 2}=\sum 1 *$ Swrvtral probabtity $y_{t: 2} * \frac{(1+0.028)^{2}}{(1+0.051)^{2}} * \frac{1}{1,013^{2}}$ 
The ratio between $A_{s l 2}$ and $A_{s l}$ represents the increase in wealth associated with experiencing less inflation erosion. State and local pension wealth is thus adjusted by this ratio to produce higher values (a 6- to 7-percent increase, depending on gender and marital status):

$N P V_{\text {penstion,sli }}-N P V_{\text {perston } s t} * \frac{A_{s l 2}}{A_{s l}}$

Finally, we annuitize state and local pension wealth assuming a 5.1 percent nominal discount rate comprised of a 2.3 percent real return on assets and 2.8 percent inflation:

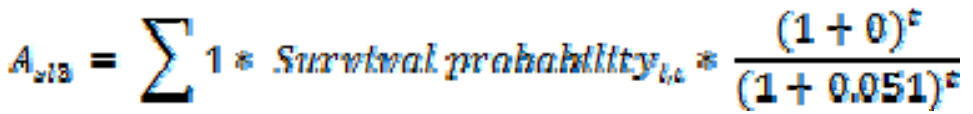

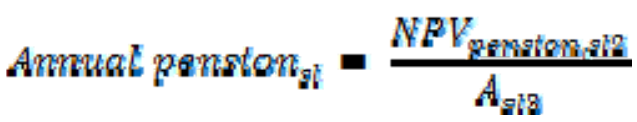

Calculating the real annuities in Appendix $\mathrm{C}$ simply requires adding an inflation adjustment to $A_{p}$ and $A_{s a g}$. The real rate of return should remain constant between the two sectors, so the COLA is set to 4 percent in the private sector and 1.5 percent in the public sector (yielding a real discount rate in each case of 1.023).

Table B1. Annuity Factors by Sector, Gender, and Marital Status

\begin{tabular}{|c|c|c|c|}
\hline & \multicolumn{2}{|c|}{ Male } & Female \\
\hline & Single & Couple & \\
\hline Nominal Annuity & & & 11.29 \\
\hline Private sector & 10.26 & 11.90 & 12.44 \\
\hline State-local sector & 11.19 & 13.15 & \\
\hline Real Annuity & & & 16.14 \\
\hline Private sector & 14.13 & 17.20 & 16.14 \\
\hline State-local sector & 14.13 & 17.20 & \\
\hline
\end{tabular}

Source: Authors' calculations using Social Security Administration life tables. 
Appendix C

Replacement Rates Calculated on the Basis of Inflation-Adjusted Annuities

Table C1. Median Replacement Rates ${ }^{a}$ for Individual Workers by Employment History

\begin{tabular}{|l|l|l|l|l|l|l|l|}
\hline \multirow{2}{*}{$\begin{array}{l}\text { Retirement } \\
\text { income source }\end{array}$} & All & $\begin{array}{l}\text { Without } \\
\text { pensions }\end{array}$ & $\begin{array}{l}\text { With } \\
\text { pensions }\end{array}$ & All & \multicolumn{3}{|c|}{$\begin{array}{l}\text { Percent of career spent in } \\
\text { state-local sector }\end{array}$} \\
\cline { 2 - 8 } & & & & $1-15 \%$ & $15-50 \%$ & $>50 \%$ \\
\hline Social Security & 29.2 & 32.4 & 27.6 & 26.4 & 27.8 & 26.5 & 23.4 \\
\hline $\begin{array}{l}\text { Social Security } \\
\text { + pensions }\end{array}$ & 38.9 & 32.4 & 43.7 & 50.1 & 43.7 & 49.0 & 63.5 \\
\hline $\begin{array}{l}\text { Addendum: } \\
\text { Percent of } \\
\text { sample }\end{array}$ & 76 & 35 & 41 & 24 & 10 & 8 & 6 \\
\hline
\end{tabular}

Table C2. Median Replacement Rates ${ }^{a}$ for Households by Employment History

\begin{tabular}{|c|c|c|c|c|c|c|c|}
\hline \multirow{3}{*}{$\begin{array}{l}\text { Retirement } \\
\text { income source }\end{array}$} & \multicolumn{3}{|c|}{ Private sector } & \multicolumn{4}{|c|}{ State-local sector } \\
\hline & \multirow[t]{2}{*}{ All } & \multirow[t]{2}{*}{$\begin{array}{l}\text { Without } \\
\text { pensions }\end{array}$} & \multirow[t]{2}{*}{$\begin{array}{l}\text { With } \\
\text { pensions }\end{array}$} & \multirow[t]{2}{*}{ All } & \multicolumn{3}{|c|}{$\begin{array}{l}\text { Percent of career spent in } \\
\text { State-local sector }\end{array}$} \\
\hline & & & & & $1-15 \%$ & $15-50 \%$ & $>50 \%$ \\
\hline Social Security & 32.0 & 35.7 & 30.9 & 29.3 & 29.7 & 29.4 & 28.3 \\
\hline $\begin{array}{l}\text { Social Security } \\
+ \text { pensions }^{b}\end{array}$ & 43.5 & 35.7 & 47.0 & 51.9 & 43.8 & 52.0 & 62.7 \\
\hline $\begin{array}{l}\text { Addendum: } \\
\text { Percent of } \\
\text { sample }\end{array}$ & 67 & 24 & 43 & 33 & 13 & 11 & 9 \\
\hline
\end{tabular}

Table C3. Median Replacement Rates ${ }^{a}$ for Households, Including Financial Assets, by Employment History

\begin{tabular}{|c|c|c|c|c|c|c|c|}
\hline \multirow{3}{*}{$\begin{array}{l}\text { Retirement } \\
\text { income source }\end{array}$} & \multicolumn{3}{|c|}{ Private sector } & \multicolumn{4}{|c|}{ State-local sector } \\
\hline & \multirow[t]{2}{*}{ All } & \multirow[t]{2}{*}{$\begin{array}{l}\text { Without } \\
\text { pensions }\end{array}$} & \multirow[t]{2}{*}{\begin{tabular}{|l} 
With \\
pensions
\end{tabular}} & \multirow[t]{2}{*}{ All } & \multicolumn{3}{|c|}{$\begin{array}{l}\text { Percent of career spent in } \\
\text { State-local sector }\end{array}$} \\
\hline & & & & & $1-15 \%$ & $15-50 \%$ & $>50 \%$ \\
\hline Social Security & 30.3 & 34.0 & 29.1 & 27.1 & 27.8 & 27.3 & 25.8 \\
\hline $\begin{array}{l}\text { Social Security } \\
+ \text { pensions }\end{array}$ & 41.5 & 34.0 & 44.6 & 48.3 & 40.6 & 48.9 & 58.3 \\
\hline $\begin{array}{l}\text { Social Security } \\
+ \text { pensions }{ }^{\mathrm{b}}+ \\
\text { Financial assets }\end{array}$ & 47.3 & 40.5 & 50.3 & 55.3 & 48.0 & 54.9 & 66.4 \\
\hline
\end{tabular}

a. The denominator is the individuals' top five years of earnings in the last ten years indexed for inflation plus income from financial assets.

b. For those with pension coverage, IRA assets are included in defined contribution wealth; for those without pension coverage, IRA assets are classified as part of financial assets.

c. The real return on financial assets is assumed to be 2.3 percent.

Source: Authors' calculations from HRS (1992-2008). 


\section{RECENT WORKING PAPERS FROM THE}

\section{CENTER FOR RETIREMENT RESEARCH AT BOSTON COLLEGE}

Do Low-Income Workers Benefit from 401(k) Plans?

Eric Toder and Karen E. Smith, September 2011

Corporate Pension Plan Investments in Alternative Assets: Determinants and Consequences

Divya Anantharaman, September 2011

Social Security Reform and Male Labor Force Participation Around the World Jocelyn E. Finlay and Günther Fink, June 2011

An In-Depth Look into Intergenerational Flows

Oksana Leukhina and Marika Santoro, May 2011

Who Retires Early?

Henry J. Aaron and Jean Marie Callan, May 2011

The Potential Impact of the Great Recession on Future Retirement Incomes Barbara A. Butrica, Richard W. Johnson, and Karen E. Smith, May 2011

Immigrant Diversity and Social Security: Recent patterns and Future Prospects Melissa M. Favreault and Austin Nichols, May 2011

Why Aren't More Families Buying Life Insurance?

Matthew S. Chambers, Don E. Schlagenhauf, and Eric R. Young, March 2011

Changes in Firm Pension Policy: Trends Away From Traditional Defined Benefit Plans Kandice A. Kapinos, February 2011

Interdependent Durations in Joint Retirement

Bo Honoré and Áureo de Paula, February 2011

Health and Retirement Effects in a Collective Consumption Model of Elderly Households Arthur Lewbel and Shannon Seitz, February 2011

Age Differences in Job Displacement, Job Search, and Reemployment

Richard W. Johnson and Corina Mommaerts, January 2011

The Earnings and Social Security Contributions of Documented and Undocumented Mexican Immigrants

Gary Burtless and Audrey Singer, January 2011

All working papers are available on the Center for Retirement Research website

(http://crr.bc.edu) and can be requested by e-mail (crr@bc.edu) or phone (617-552-1762). 